\title{
A Trial to Prevent Salmonella Enteritidis Infection in Broiler Chickens Using Autogenous Bacterin Compared with Probiotic Preparation
}

\author{
Wafaa A. Abd El-Ghany (Corresponding author) \\ Department of Poultry Diseases, Faculty of Veterinary Medicine, Cairo University, Giza -12211, Egypt \\ Tel: 202-122-440-7992Ｅ-mail: wafaa.ghany@yahoo.com
}

Soumaya S.A. El-Shafii

Department of Serology, Animal Health Research Institute, Dokki, Giza-12211, Egypt

Tel: 202-145-713-431 E-mail: soumayaelshafii@yahoo.com

M.E. Hatem

Department of Microbiology, Faculty of Veterinary Medicine, Cairo University, Giza -12211, Egypt

Tel: 202-100-604-3056 E-mail: eh_hatem@yahoo.com

Rehab E. Dawood

Animal Health Research Institute, Demitta, Egypt

Tel: 202-100-715-4798_E-mail:mr.hotmail10@yahoo.com

$\begin{array}{ll}\text { Received: December 16, } 2011 & \text { Accepted: January 9, } 2012 \quad \text { Online Published: April 1, } 2012 \\ \text { doi:10.5539/jas.v4n5p91 } & \text { URL: http://dx.doi.org/10.5539/jas.v4n5p91 }\end{array}$

\begin{abstract}
This study was carried out to investigate the efficacy of the locally prepared autogenous Salmonella Enteritidis ( $S$. Enteritidis) bacterin as well as a probiotic preparation in the prevention of broiler chickens from $S$. Enteritidis infection. A total of three hundred and ten, one day-old Hubbard broiler chicks were used. At day old, ten chicks were sacrificed and examined bacteriologically to prove their freedom from $S$. Enteritidis infection. Three hundred birds were divided into four equal groups. Chickens in group (1) were kept as blank control negative non infected-non treated birds, while those of group (2) were challenged non treated birds. Group (3) was vaccinated intramuscularly by the autogenous bacterin at the first day of age in a dose of $0.2 \mathrm{ml} / \mathrm{bird}$ and boostered as a second dose at 10 days of age in a dose $0.5 \mathrm{ml} /$ bird, however, group (4) was given a commercial probiotic preparation as $1 \mathrm{gm} / 4$ liter of the drinking water from the first day of age and continued for 5 successive days. All birds in groups 2, 3, and 4 were challenged orally by $0.5 \mathrm{ml}$ containing $10^{9} \mathrm{CFU} / \mathrm{ml} S$. Enteritidis at 20 days of age. All the groups were kept under complete observation for three weeks for recording signs, moralities, gross lesions, shedding rate of $S$. Enteritidis, re-isolation of the organism, the performance as well as detection of the titer of antibodies serologically using microagglutination test and enzyme linked immunosorbant assay (ELISA) test. The results showed that the both the bacterin and the probiotic are equally effective in reducing signs, mortalities, gross lesions, the shedding rate and the re-isolation of $S$. Enteritidis and also increasing in the performance of chickens. The effect of the bacterin and the probiotic was significant $(\mathrm{P} \leq 0.05)$ when compared with the infected non treated chickens. Moreover, the serological investigation revealed an improvement in the titer of antibodies after vaccination and probiotic treatment. In conclusion, double doses of locally prepared autogenous $S$. Enteritidis bacterin and the probiotic preparation were effective and safe methods for prevention of $S$. Enteritidis infection in broiler chickens.
\end{abstract}

Keywords: Salmonella Enteritidis, Prevention, Bacterin, Probiotic 


\section{Introduction}

Salmonella typhoid and paratyphoid caused by several species of Salmonellae infections are recognized worldwide as important food borne human diseases. Approximately 13 million cases of paratyphoid infections occur worldwide annually (Murugkar et al., 2005). Unfortunately, poultry meat is the major source of food borne Salmonella paratyphoid infection (Mayrhofer et al., 2003). Riemann et al., (1998) demonstrated an increase in the number of Salmonella Enteritidis ( $S$. Enteritidis) isolates from humans in United States from 1.12 to 7.16 isolates per 100.000 person per year as this serotype accounted for $28 \%$ of all Salmonellae isolates for human. As well, Herikstad et al., (2002) considered $S$. Enteritidis the most common species of Salmonellae that isolated worldwide.

In addition to the public health impact, infection with $S$. Enteritidis in poultry causes serious economic losses due to high rate of mortality (4-50\%), loss of weight and decreased in egg production (Hoop 1997).

Besides good hygiene and bird's husbandry practice, several methods have been currently employed to reduce $S$. Enteritidis infections in poultry farms such as using of preventative feed medication or antibiotic growth promoters (Dekich 1998), using of competitive exclusion products like probiotics and development of vaccines (Lillehoj et al., 2000).

Control of $S$. Enteritidis infection using antimicrobials emerges the problem of antimicrobial resistance (Zhang-Barber et al., 1999). Therefore, alternative safe strategies are emerged to overcome this important problem.

Priyantha (2009) reported that vaccination is only alternative to control salmonellosis in chickens and other precaution like bio-security and good management practices must be taken to consideration first. There are numbers of live and killed $S$. Enteritidis vaccines used commercially worldwide with some success. The efficacy of live attenuated S. Enteritidis vaccines was studied (Arnon et al., 1983; Barrow et al., 1990; Barrow 2000 and 2007; Atterbury et al., 2010; Penha et al., 2010; Methner et al., 2011) and the vaccine proved its efficacy but it could be hazardous because of residual virulence caused by insufficient attenuation, reversion to virulence and uncertain safety (Barbezange et al., 2000), so its use is prohibited in several countries. However, inactivated $S$. Enteritidis vaccine had been developed and can confer partial protection against intestinal colonization, fecal shedding, systemic spread and egg contamination (Timms et al., 1990; Gast et al., 1993; Nakamura et al., 1994; Timms et al., 1994; Davison et al., 1999; Miyamoto et al., 1999; Liu et al., 2001; Khan et al., 2003; Okamura et al., 2003; Nakamura et al., 2004; Haider et al., 2007; Cima 2010).

Reducing intestinal colonization with $S$. Enteritidis using competitive exclusion compounds (probiotics) during the grow-out period is crucial to improve the microbiological quality at processing as well as for consumer health (Vugia 1993). Probiotics consist of live or dead organisms and spores (Patterson and Burkholder 2003), non-traditional chemicals (Moore et al., 2006), bacteriophages (Higgins et al., 2005), organic acids (Jarquin et al., 2007; Wolfenden et al., 2007) and others have emerged in the last decades as some of the tools that could be potentially useful in the near future for pathogen control and poultry performance. Probiotics are used now safely to prevent enteric infections especially with $S$. Enteritidis in newly hatched chicks with successful results (Soerjadi et al., 1981; Fuller 1997; Tellez et al., 2001; Ayed et al., 2004; Wafaa et al., 2006; Higgins et al., 2007a, b; Revolledo et al., 2009).

So, the present work was designed to evaluate the role of the locally prepared killed $S$. Enteritidis bacterin compared with a commercial probiotic preparation in the prevention of $S$. Enteritidis infection in broiler chickens.

\section{Material and Methods}

\subsection{Experimental Chickens}

A total of three hundred and ten, day-old Hubbard broiler chicks of mixed sex that obtained from Cairo Poultry Company in $10^{\text {th }}$ Ramadan city were used for evaluation of the protective value of the prepared $S$. Enteritidis bacterin in comparison with a probiotic against $S$. Enteritidis challenge. The chicks were taken from a breeder flock free from salmonellosis. The birds were kept under complete observation for six weeks (experimental period) in separate thoroughly cleaned and disinfected houses and provided with feed and water adlibitum. All the birds were vaccinated against Newcastle disease (ND) using live Hitchner B1 and La Sota vaccine strains at 6 and 19 days of age, respectively, against infectious broncheitis (IB) disease using live H 120 strain at 6 day old and also against avian influenza (AI) disease using inactivated H5 N1 reasortant virus vaccine strain a 7 days old. Vaccination against infectious bursal disease (IBD) was applied using live intermediate strain (228 E) at 14 days 
of age. All the vaccines were given via eye drop instillation except (AI) vaccine which given through subcutaneous route at the back of the neck.

\subsection{The Ration}

Commercial starter and grower broiler chicken ration were given till 21 and 35 days of age, respectively, while finisher ration was used till 42 days of age (end of the experiment). The used commercial balanced ration based on yellow corn or soyabean that met the National Research Council (NRC) (1984) broiler chicken requirements. The starter ration contained crude protein-not less than $21 \%$, crude fat-not less than $2.94 \%$, crude fibers-not less than $2.35 \%$, metabolizing energy-not less than $3054 \mathrm{Kcal} / \mathrm{kg}$ ration and used for the first 3 weeks of age. The grower and finisher ration contained crude protein-not less than $17.15 \%$, crude fat-not less than $2.5 \%$, metabolizing energy-not less than $3020 \mathrm{Kcal} / \mathrm{kg}$ ration and used for the remaining of the experimental period. The ration contained coccidiostate (semduramicin) while no antibiotics were added to it.

\subsection{The Used Probiotic}

The probiotic that used in the experiment was a commercial preparation containing (Lactobacillus acidophilus, Enterococcus faecium, Lactobacillus plantarum and Lactobacillus casei) plus potassium, vitamins A, D3, E and $\mathrm{K}$, riboflavin, pantothenic acid, thiamine and niacinamide. That product was manufactured by Bomac Vets Plus, USA. Batch No., A704. It was given in the drinking water at the age of one day for 5 consecutive days in a dose of $1 \mathrm{gm} / 4$ liter of the drinking water as recommended by manufacturer.

\subsection{The Challenge Inoculum}

Broth culture of $S$. Enteritidis field strain was centrifuged at 3000 r.p.m for 10 min. Sediment was diluted with sterile buffer saline and adjusted using MacFerland matching tube to contain $10^{9} \mathrm{CFU} / \mathrm{ml}$. The challenge inoculum was prepared according to the method of Timms et al., (1990). At 20 days of age, each bird in the experimentally infected groups was inoculated orally with $0.5 \mathrm{ml} /$ containing $10^{9} \mathrm{CFU} / \mathrm{ml} S$. Enteritidis (Okamoto et al., 2007).

\subsection{Preparation of Local Salmonella Enteritidis Bacterin}

The bacterin was prepared from $S$. Enteritidis field strain according to the technique of Timms et al., (1990). The strain of $S$. Enteritidis was transferred from semi-solid media to nutrient broth and incubated at $37^{\circ} \mathrm{C}$ for $24 \mathrm{hr}$, then to nutrient agar and incubated at $37^{\circ} \mathrm{C}$ for $24 \mathrm{hr}$, after which it was grown on brain heart infusion agar and kept at $37^{\circ} \mathrm{C}$ for $48 \mathrm{hr}$ in Roux flask. Growth was harvested in normal saline and inactivated with $1 \%$ formol saline for $24 \mathrm{hr}$ at room temperature. Using MacFerland matching tube, washed concentrates of inactivated bacteria were suspended in saline and adjusted to contain $10^{11} \mathrm{CFU} / \mathrm{ml}$. Sterile bacterin was obtained by adding equal volume of incomplete Ferund's adjuvant to adjusted washed concentrate of inactivated bacteria and kept at refrigerator until used. The prepared whole cell inactivated $S$. Enteritidis bacterin was given for the experimental chicks at the first day of age in a dose of $0.2 \mathrm{ml} / \mathrm{bird}$ and boostered as a second dose at 10 days of age in a dose $0.5 \mathrm{ml} / \mathrm{bird}$. The bacterin in the two shots was given intramuscularly $(\mathrm{I} / \mathrm{M})$ in the thigh muscles.

\subsection{Quality Control Tests of the Prepared Bacterin}

The prepared $S$. Enteritidis bacterin was tested for purity, complete inactivation, sterility and safety according to the Standard International Protocols as described by the British Veterinary Codes (1970) as follows:

\subsubsection{Purity Test}

The test was done before formalin inactivation of $S$. Enteritidis strain. It was applied to confirm that the broth culture of $S$. Enteritidis strain did not contain any contamination by other organisms before inactivation. Such purity was detected by inoculation of the broth culture onto Salmonella Shegella (S. S) agar and inocubated at $37^{\circ} \mathrm{C}$ for $24 \mathrm{hr}$. Appearance of pure colonies of $S$. Enteritidis and pure $S$. Enteritidis organism after Gram staining of the organism indicated culture purity.

\subsubsection{Completion of S. Enteritidis Inactivation}

In assurance that the used $S$. Enteritidis organisms were completely inactivated, S. S agar media was inoculated with formalin inactivated bacteria. After $24-48 \mathrm{hrs}$ of incubation at $37^{\circ} \mathrm{C}$, no visible growth of $S$. Enteritidis indicated complete inactivation of the organism.

\subsubsection{Sterility Test}

The prepared $S$. Enteritidis bacterin was confirmed to be free from any fungal contaminants by inoculation of it onto Sabouraud Dextrose Agar (SDA) plates and incubated at $25^{\circ} \mathrm{C}$ for 7 days. Also the bacterin was inoculated 
on Pleuropneumonia Like Organism (PPLO) broth tubes and agar plates and incubated at $37^{\circ} \mathrm{C}$ for $72 \mathrm{hrs}$ and 14 days, respectively in $\mathrm{Co}_{2}$ incubator to ensure the freedom of the bacterin from mycoplasma organisms.

\subsubsection{Safety Test}

Ten, day old broiler chicks were inoculated intramuscularly (I/M) with a large dose of the prepared bacterin (ten fold the normal bacterin dose). The chicks were observed daily for 7 successive days for any signs of local reactions, clinical signs or deaths.

\subsection{Experimental Design}

Three hundred and ten, one day-old Hubbard broiler chicks of mixed sex were used. At arrival, randomly ten chicks were sacrificed and then examined bacteriologically to prove their freedom from $S$. Enteritidis infection. A completely randomized design was used as three replicates, each consists of 25 chicks and the groups were divided as the followings;

Group (1): Blank control negative (non infected-non treated birds).

Group (2): Infected non treated ( $S$. Enteritidis infected birds).

Group (3): (Vaccinated and $S$. Enteritidis infected birds).

Group (4): (Probiotic treated and $S$. Enteritidis infected birds).

\subsection{The Measured Parameters for Evaluation of the Bacterin Efficacy in Comparison with the Probiotic}

\subsubsection{Clinical Signs, Mortalities and Gross Lesions}

Birds in the challenged groups were observed daily for three weeks post challenge till the end of the study (6 weeks of age) for the clinical signs or deaths. Dead birds were subjected to necropsy for recording the lesions of S. Enteritidis (O'Brien 1988).

\subsubsection{Detection of the Shedding of $S$. Enteritidis}

Cloacal swabs were taken from birds in each group just before experimental infection (at 20 days of age) to ensure that the birds free from $S$. Enteritidis infection. Weekly after the challenge up to 6 weeks of age, cloacal swabs were collected from each of the infected as well as control group and examined bacteriologically for the presence of $S$. Enteritidis organism. Sterile cotton swab was inserted into the cloaca of each bird and rotated gently to collect the clocal contents. Each swab was transferred to $10 \mathrm{ml}$ tube of tetrathionate broth and incubated overnight at $37^{\circ} \mathrm{C}$. A loopful from the broth was streaked on S.S agar for Salmonella isolation. Suspected colonies were identified morphologically and biochemically.

\subsubsection{Re-isolation of $S$. Enteritidis}

Ten birds from each group post challenge were weekly randomly selected, sacrificed and the liver, heart, spleen and caecum were collected for $S$. Enteritidis re-isolation. Samples were inoculated into tetrathionate broth, incubated at $37^{\circ} \mathrm{C}$ for $24 \mathrm{hr}$, streaked onto S.S agar and incubated at $37^{\circ} \mathrm{C}$ for $24 \mathrm{hr}$. Suspected colonies were identified morphologically and biochemically.

\subsubsection{The Performance}

At arrival, the chicks were weighed and then the birds in each group were subjected to weekly determination of the production parameters that include; the body weight (BW), the cumulative feed conversion (CFC) and the European Production Efficiency Factor (EPEF) according to Sainsbury (1984). These measures were taken till the end of the study ( 6 weeks of age).

\subsubsection{Detection of the Humoral Immune Response}

Just before the first $S$. Enteritidis vaccinal dose (at zero hour), a randomly ten identified birds were selected and the blood samples were collected via the brachial vain. Also just before the second booster dose of $S$. Enteritidis vaccination (10 days after the first dose), another blood; samples were collected as previously from the same marked birds. Blood samples were collected weekly after the second vaccination till 6 weeks of age (end of the study). The collected blood samples were allowed to clot overnight at $4{ }^{\circ} \mathrm{C}$ then centrifuged at $3000 \times \mathrm{xg}$ for $10 \mathrm{~min}$. The separated sera were stored at $-20^{\circ} \mathrm{C}$ till used in the serological tests. The antibody titer against $S$. Enteritidis was determined using Microagglutinaion test (MAT) and indirect Enzyme Linked Immuno-Sorbent Assay (ELISA) test.

\section{Micro agglutination test (MAT)}

It was done as Williams and Whittemore (1971) and Brown et al., (1981). 


\section{Indirect Enzyme-Linked Immunosorbent Assays (ELISA)}

This test was applied according to the method of Kim et al., (1991) and Barrow (1992).

\subsection{Statistical Analysis}

The statistical analysis of data of protection, faecal shedding and re-isolation was carried out using Chi-Square (Greenwood and Nikulin 1996). The statistical analysis of average body weight and ELISA data were examined using One-Way analysis of variance (ANOVA) according to Shott (1990).

\section{Results and Discussion}

Although $S$. Enteritidis infection in chicken broilers or layers sometimes sub-clinical, but poultry products are considered as important sources for human food borne outbreaks (Bielke et al., 2003). In terms of the loss to producers annually, it is difficult to estimate, however any strategies which reduce the incidence of salmonellosis in poultry are clearly important to all facts of the industry. Reducing Salmonella incidence has become monitored and regulated by Food Safety and Inspection Service (Helmick et al., 1994). Wilkie (2006) and Rahimi et al., (2007) suggested using of alternatives rather than antimicrobial therapy for controlling enterobacteria. It has been accepted worldwide that vaccination to prevent or reduce Salmonella infection in poultry is practical (Barrow 2007). In big poultry producing countries, commercial vaccines are commonly used in layers as well as broilers to control the outbreaks of salmonellosis (Paiva et al., 2009). Antimicrobial feed additives such as antibiotics and synthetic antimicrobial agents have been used extensively in poultry feed to suppress or eliminate harmful intestinal pathogens and to improve both growth and feed efficiency (Jin et al., 1997). However, the continued feeding of antibiotics at sub-therapeutic levels usually increase the possibilities of antibiotic residue, the development of drug-resistant bacteria and additionally a reduction in the ability to cure bacterial infections in humans (Jensen 1998), because of that, the routine use of antibiotics as feed additives and growth promoters has been banned in some European countries since 1986 (Van Belle 2001). Probiotics, such as lactic acid-producing bacteria and yeast have been reported to improve gastrointestinal balance through bacterial antagonisms, competitive exclusion and immune stimulation (Havenaar and Huisint 1992).

The quality control tests of the locally prepared whole cell inactivated $S$. Enteritidis bacterin revealed that the bacterin was pure (contained only $S$. Enteritidis organisms) as confirmed by Gram staining. Microscopically, there were Gram negative, straight and non spore forming $S$. Enteritidis organisms. The bacterin was completely inactivated as there was no growth on S. S agar media. Also, the prepared bacterin was sterile without fungal or mycoplasmal growth contamination as indicated by absence of growth on SDA and PPLO broth or agar, respectively. No local reactions, signs or deaths were observed after bacterin I/M inoculation in the chicks and that ensure the safety of the bacterin. Young and Kang (2005) reported on the safety and efficacy of $S$. Gallinarum bacterin when applied in young layer chicks.

In the present study, Three hundred, day old broiler chicks were used and divided into four groups and submitted for vaccination with locally prepared $S$. Enteritidis bacterin or treated with probiotic, and then experimentally infected with $S$. Enteritidis to evaluate the efficacy of both tools in protection from infection.

The results of experimental infection of broiler chickens at 20 days old after vaccination with the locally prepared $S$. Enteritidis bacterin and treatment with the probiotic indicated that infected groups $(2,3$ and 4$)$ manifested signs of depression, anorexia and watery diarrhea 3 days post challenge. The severity of signs was highly in the birds that infected only (group 2) than those vaccinated or probiotic treated (group 3 and 4). The morbidity rates were 80,30 and $20 \%$ in the only infected, vaccinated infected and probiotic treated and infected groups, respectively. S. Enteritidis may produce clinical disease in chicks up to six weeks of age and occasionally in adult laying birds. Affected birds are depressed, reluctant to move and commonly have diarrhoea (Wray et al., 1996).

Table (1) shows that the mortality rate $30.67 \%$ in infected non treated birds, $5.33 \%$ in vaccinated infected birds and $12 \%$ in probiotic treated infected ones. Dead birds were subjected to post-mortem examination for specific $S$. Enteritidis lesions. Lower mortality rate in broilers was recorded by Samanta and Biswas (1995) after treatment with probiotics. The most predominant lesions were congestion of muscles and internal organs and inflammation of the intestinal mucosa with mucoid intestinal contents. The lesions were markedly severe in infected non treated broilers than treated ones. Lister (1988) recorded nearly similar lesions caused by $S$. Enteritidis in broiler chickens.

From table (1), the results clear that there is a significant $(\mathrm{P} \leq 0.05)$ difference in the protection rate between the infected non treated group and the vaccinated and probiotic treated groups. The protection rate of the locally prepared $S$. Enteritidis bacterin and the probiotic in birds are $82.61 \%$ and $60.87 \%$, respectively which is 
significantly $(\mathrm{P} \leq 0.05)$ higher than infected non treated birds $(0 \%)$. These results agreed with Gast et al., (1993); Timms et al., (1994); Feberwee et al., (2000 and 2001a, b) who proved that $S$. Enteritidis bacterin was highly protective for broiler or layer chicken flocks when using signs, mortalities and post-mortem lesions as criteria for measuring the protective index. Ghosh (1989) reported that vaccination of broilers with $S$. Virchow formalin killed bacterin reduced mortalities from 85 to $0 \%$. Also, Timms et al., (1990) found decline in mortalities from 100 to $50 \%$ in $S$. Enteritidis bacterin inoculated broiler chickens.

The protective efficacy of the probiotics which contained Lacobacillus spp. against $S$. Enteritidis infection was evaluated by Samanta and Biswas (1995); Soomro et al., (2002); Timmerman et al., (2006); Wafaa et al., (2006) who detected significant decrease in mortality in $S$. Enteritidis infected chickens and treated with probiotic than infected ones. Higgins et al., (2007 a, b) and Vicente et al., (2007 a, b) concluded that effective probiotics may accelerate the development of normal microflora in chicks and increased the resistance to infection by some enteric bacterial pathogens. Lactobacilli have been widely reported to produce antibacterial compounds called bacteriocins and the effect of bacteriocins have been hypothesized to be the mechanism by which Lactobacilli exert cytotoxic effects in vivo (Bogovic-Matijasic et al,. 1998; Ocan et al., 1999). They also hypothesized that a soluble peptide could mediate the reduction of $S$. Enteritidis.

The results of the faecal shedding rate of $S$. Enteritidis in broiler chickens after vaccination with the locally prepared bacterin and treatment with probiotic is illustrated in table (2). The results declare that there are significant $(\mathrm{P} \leq 0.05)$ differences between the vaccinated and probiotic treated groups and the infected non treated one along three weeks observation period. Gradual and significant $(\mathrm{P} \leq 0.05)$ decrease in the shedding rate is observed within each group until reached the last week of observation period. The faecal shedding rate in the vaccinated birds collectively is $9.24 \%$ and in the probiotic treated one is $17.5 \%$ which is significantly $(\mathrm{P} \leq 0.05)$ lower than infected non treated birds (40.6\%). There was a considerable difference between the carriage of Salmonella in the cecal contents, indicating that broilers were able to clear systemic infections but could remain intestinal carriers (Bjerrum et al., 2003). So, the intestinal carrier status was most important in control of $S$. Enteritidis contamination during transportation and processing of broilers, where cross contamination played a major role (Gurtler et al., 2004; Dorea et al., 2010).

The role of formalin inactivated whole cell $S$. Enteritidis oil emulsion bacterin in reducing the shedding rate of the organism after examination of the cloacal swabs was tested by Barbour et al., (1993); Gast et al., (1993); Nakamura et al., (1994); Liu et al., (2001); Clifton-Hadley et al., (2002); Davis and Breslin (2003); Okamura et al., (2003); Davis and Breslin (2004); Radwan (2007) and they concluded that this type of vaccine was very effective or significant in reducing the $S$. Enteritidis faecal shedding rate in vaccinated chickens when compared with non vaccinated control birds.

Concerning the reducing effect of the probiotics on S. Enteritidis shedding rate, the results of Tellez et al., (2001) and Rahimi et al., (2007) in broilers and Fulton et al., (2002) in duckling are parallel with our results.

The results of the re-isolation rate of $S$. Enteritidis from different organs of sacrificed broiler chickens after vaccination with the locally prepared bacterin and treatment with the probiotic are shown in table (3). These results indicate that along the whole three weeks observation period, the highest and significant $(\mathrm{P} \leq 0.05)$ re-isolation rate in the infected non treated broiler chickens is $(46.67 \%)$, while this rate is significantly $(\mathrm{P} \leq 0.05)$ lower in the probiotic treated birds $(21.67 \%)$ until it reaches its lowest and significant $(\mathrm{P} \leq 0.05)$ level in the vaccinated ones (11.67\%). The results of Bolder and Palmu (1995) proved the possibility of $S$. Enteritidis to become extra-intestinal and invade the liver week post infection. It was documented that the frequency of $S$. Enteritidis re-isolation from the internal organs (liver and spleen), the intestine (caecum) and the eggs (shells or contents) was significantly reduced in vaccinated broilers and layers with multiple doses of $S$. Enteritidis oil emulsion bacterin than non vaccinated controls (Gast et al., 1993; Nakamura et al., 1994; Timms et al., 1994; Davison et al., 1999; Miyamoto et al., 1999; Khan et al., 2003; Okamura et al., 2007; Radwan et al., 2007). Young et al., (2007) detected that vaccination against Salmonellae in breeders could reduce the colonization of the organism in the hatched broiler chicks. As well, Penha et al., (2009) and Priyantha (2009) found that vaccination of layers and breeders with inactivated $S$. Enteritidis vaccine induced significant reduction of organ (spleen, liver and caeca) colonization after challenge. Nevertheless, Clifton-Hadley et al., (2002) mentioned that there was no effect of vaccination on internal organs colonization after oral challenge with $S$. Typhimurium.

The reducing effect of probiotics on the colonization by Salmonella spp. was studied comprehensively by several researchers. It was reported that probiotics maintained or increased the normal intestinal flora which are normally found in the intestinal tract of hatched birds and these flora can exclude Salmonellae colonization (Goren et al., 1988; Starvic 1992; Barbour et al., 1993; Nisbet et al., 1996; Mead 2000; Seo et al., 2000). 
Contrary results were mentioned by Seuna et al., (1980) who found that supplementation of the birds with normal avian gut microflora didn't prevent or only partially prevent Salmonella colonization. This inconsistent may be due to the difference in the strains of bacteria that present in the culture. There are many hypotheses that explain the mechanism of action of lactic acid bacteria against Salmonellae colonization in birds; one of them is that production of lactic acid which is unfavorable $\mathrm{pH}$ for growth of Salmonellae (Alkoms et al., 2000; Rolfe 2000; Johanssen et al., 2004), the competition between Lactobacilli and the enteric bacteria which is called competitive exclusion (Heres et al., 3003), also the production of bacteriocin which is antibacterial substances that kill enterobacteriacae (Pascual et al., 1999).

Concerning the results of the performance of each group after vaccination with the locally prepared $S$. Enteritidis bacterin and treatment with the probiotic, they are seen in table (4). The measured parameters including the average body weight (BW), the cumulative feed conversion (CFC) and European production efficiency factor (EPEF) show significant $(\mathrm{P} \leq 0.05)$ improvement in the vaccinated and probiotic treated groups than infected non treated one along the whole course of the study ( 6 weeks of age). The best CFC is observed in the vaccinated and probiotic treated broilers (1.89 and 1.78, respectively), while the worst one is in the infected non treated birds (2.43).

Our results are in agreement with that recorded by Mohrah and Zaki (1995) who demonstrated that vaccination of chickens with Salmonella Gallinarum Pullorum bacterin induced significant increase in the body weight of birds.

Most of the published studies regarding the effect of probiotics (especially those containing Lactobacillus spp.) on bird's performance in case of absence of enteric infections revealed that these compounds are effective as they improve the growth of the broiler chickens (Mohan et al., 1996; Jin et al., 1998; Zulkifli et al., 2000; Kalvathy et al., 2003; Gracia et al., 2004; Huang et al., 2004; Opalinski et al., 2007; Midilli et al., 2009). On the other hand, Angle et al., (2005) found no improvement in performance but there were increased protein, calcium and phosphorus retention. In case of $S$. Enteritidis infection, Fairchild et al., (2001); Tellez et al., (2001); Wafaa et al., (2006); Wilkie et al., (2006); Rahimi et al., (2007) demonstrated that probiotics containing lactobacilli could overcome the growth depressing effect caused by this infection. The improvement in the performance parameters caused by probiotic administration may be due to stimulating the host's appetite (Nahashon et al., 1992), improving feed conversion ratio (Cavit 2003; Ayed et al., 2004), producing digestive enzymes (Saarela et al., 2000), synthesizing of vitamins (Coates and Fuller 1977), stimulating lactic acid production (Bailey 1987) and the beneficial effect on the health of the host (Soomro et al., 2002).

Results listed in table (5) show the titer of antibodies against $S$. Enteritidis after vaccination with the locally prepared bacterin and treatment with the probiotic using microagglutination test. After the $1^{\text {st }}$ dose of bacterin administration and probiotic treatment, the geometric mean titer (GMT) of antibodies increases to reach 65 in vaccinated group and 60.6 in the probiotic treated birds. After booster dose of vaccination (before challenge), GMT increases to reach 98 and 74.5 in vaccinated and probiotic treated birds, respectively. A week after $S$. Enteritidis challenge, the GMT increases to reach 60.6, 211.1 and 113.1 in the infected non treated, vaccinated and probiotic treated birds, respectively. Moreover, two weeks post challenge, GMT increases in the infected treated chickens and the vaccinated ones up to 139.3 and 242.5, respectively, but it declines in the probiotic treated chickens to reach 171 .

For evaluation of humoral immune response of chickens to $S$. Enteritidis vaccination and probiotic, ELISA test was done. Table (6) reveals that during the whole experimental period, the blank control non infected group shows no significant $(\mathrm{P} \leq 0.05)$ differences in the mean optical densities values. However, there is no significant $(\mathrm{P} \leq 0.05)$ difference in optical densities values in $\mathrm{S}$. Enteritidis infected, non treated birds till 20 days of age (before challenge) but these values increase significantly $(\mathrm{P} \leq 0.05)$ at 27 days of age to reach (1.781) then decrease at 34 and 41 days of age to 1.457 and 1.274, respectively. Vaccinated group shows gradual and significant $(\mathrm{P} \leq 0.05)$ increase in optical densities values from 0.234 prior vaccinations to 1.614 before booster dose (10 days old) and to 2.543 after booster dose (at 20 days old), then significant ( $\mathrm{P} \leq 0.05)$ increase in these values at 27,34 and 41 days old is observed. Furthermore, in the probiotic treated birds, gradual and significant $(\mathrm{P} \leq 0.05)$ increase in optical densities values to reach 0.234 then 0.561 at day and 10 days old, respectively is detected. These values are increased significantly $(\mathrm{P} \leq 0.05)$ at 27,34 and 41 days of age.

Barrow and Lovell (1991) and Olabisi and Peter (2008) reported on production of high level of serum IgG after oral inoculation of $S$. Enteritidis in layer chickens. The enhancement of the immune response of $S$. Enteritidis infected birds to vaccination by the locally prepared bacterin was mentioned by Barbour et al., (1993); Gast et al., (1993); Methner et al., (1994); Methner and Steinbach (1997); Okamura et al., (2003); Davies and Breslin 
(2004); Pakpinyo et al., (2008) as they detected that $S$. Enteritidis bacterin induced high level of circulating specific $\mathrm{IgG}$ against un-specified protein antigen.

Most of the studies pertaining to using of bacterins have investigated post-vaccine $S$. Enteritidis shedding over time (Woodward et al., 2003; Piao et al. 2007). Only a few have looked at the immune response following vaccination, and these studies were limited to young chickens (less than four weeks old) (Liu et al., 2001; Babu et al., 2004; Okamura et al., 2004).

Penha et al., (2009) detected that vaccination of layers and breeders with inactivated $S$. Enteritidis vaccine induced significant increased in the antibody titers as measured by ELISA. Furthermore, Tran et al., (2010) demonstrated that immunization of chickens with inactivated $S$. Enteritidis vaccine in two shots induced increasing in ELISA seroconversion (serum IgG response) which persisted up to from 3 to 32 and 34 week post-vaccination. Contrary findings were obtained by Babu et al., (2004) which had different opinions on the protective effect of vaccination against $S$. Enteritidis. The serum antibody titers were of uncertain values as indicators of the extent of protection against Salmonella, even if a killed vaccine could induce a high $S$. Enteritidis-specific antibody level, it did not necessarily protect the chickens against $S$. Enteritidis infection.

Our findings concerning the immunopotantiation caused by probiotic administration concur with Pollmann et al., (1980); Zulkifli et al., (2000); Toms and Powvie (2001); Huang et al., (2004); Koenen et al., (2004). Also, Sevage et al., (1996) and Panda et al., (2000) demonstrated an increase in the serum immunoglobulins IgG and IgA after administration of competitive exclusion cultures. Abdel-Alim et al., (2006) demonstrated an increase in the haemagglutinaing antibody titers in ochratoxicated immunosuppressed chickens after treatment with a probiotic than non treated birds. Moreover, Lee et al., (2007); Rowghani et al., (2007) and Alkhalf et al. (2010) reported that broiler chickens fed a diet supplemented with probiotic had a significant increase in the Newcastle antibody titers than control group. The enhancement of immunity in $S$. Enteritidis-probiotic treated birds was recorded by Wafaa et al., (2006) and Revolledo et al., (2009). The positive effect of feeding diet containing probiotic on the immune response indicates the enhancement of the formulating bacteria on an acquired immune response exerted by $\mathrm{T}$ and $\mathrm{B}$ lymphocytes. The direct effect might be related to stimulate the lymphatic tissue (Kabir et al., 2004), whereas the indirect effect may occur via changing the microbial population of the lumen of gastrointestinal tract or through the reduction of $S$. Enteritidis colonization. Shoeib et al., (1997) reported that the bursa of probiotic-treated chickens showed an increase in the number of follicles with high plasma cell reaction in the medulla. Christensen et al., (2002) suggested that some of these effects were mediated by cytokines secreted by immune system cells stimulated with probiotic bacteria. On the other hand, Okamoto et al., (2007) demonstrated that this type of treatment had few beneficial effects for chicks, particularly during the first days of life.

\section{Conclusions}

From this study, it could be concluded that both the locally prepared autogenous $S$. Enteritidis bacterin in double doses and the probiotic preparation are effective and safe methods for prevention of $S$. Enteritidis infection in broiler chickens. It should be taken in consideration that the vaccine or the probiotic must be go parallel to bio-security measures and good management practices to eradicate $S$. Enteritidis infection in poultry flocks.

\section{References}

Abdel-Alim, G. A., Madian, K., Ahmed, K. A., El-Nabarawy, A. \& Awaad, M. H. H. (2006). Ameliorating effect of immunostimulant on ochratoxicated broiler chickens. $7^{\text {th }}$ Sci. Conf. Egypt. Vet. Poult. Med. Associ., March, 6-9 $9^{\text {th }}$ 2006. pp. 110-128.

Alkhalf, A., Alhaj, M. \& Al-Homidan, I. (2010). Influence of probiotic supplementation on immune response of broiler chicks. Egypt. Poult. Sci., 30 (I), 271-280.

Alkoms, H. L., Skytta, E., Saaela, M., Maltila Sandhalm, T., Latra Kala, K. \& Helender, I. M. (2000). Lactic acid permeabilizes Gram-negative bacteria by disturbing the outer membrane. Appl. Environ. Microbiol., 66, 2001-2005. http://dx.doi.org/10.1128/AEM.66.5.2001-2005.2000

Angel, R., Daloul, R. A. \& Doerr, J. (2005). Performance of broiler chickens fed diets supplemented with a direct-fed microbial additives. Poult. Sci., 84, 1222-1231.

Arnon, R.M., Shapira, A. \& Jacob, C.O. (1983). Synthetic vaccines. J. Immunol. Methods, 61, 261-273. http://dx.doi.org/10.1016/0022-1759(83)90220-X 
Atterbury, R. J., Davies, R. H., Carrique-Mas, J. J., Morris, V., Harrison, D., Tucker, V. \& Allen, V. M. (2010). Effect of delivery method on the efficacy of Salmonella vaccination in chickens. Vet. Rec., 167 (5), 161-164. http://dx.doi.org/10.1136/vr.b4884

Ayed, M. H., Laamari, Z. \& Rekik, B. (2004). Effects of incorporating an antibiotic "avilamycin" and a probiotic "activis" in broiler diets. Proc. West. Sci. Amer. Soci. Anim. Sci., 55, 237-240.

Babu, U. D. R., Okamura, M. \& Lillehoj, H. S. (2004). Salmonella Enteritidis clearance and immune responses in chickens following Salmonella vaccination and challenge. Vet. Immunol. Immunopathol., 101, 251-257. http://dx.doi.org/10.1016/j.vetimm.2004.05.002

Bailey, J. S. (1987). Factors affecting microbial competitive exclusion in poultry overview outstanding symposia in food science and technology. Food Technol., 5, 88-92.

Barbezange, C., Humbert, F., Rose, V., Lalande, F. \& Salvat, G. (2000). Some safety aspects of Salmonella vaccines for poultry: distribution and persistence of three Salmonella Typhimurium live vaccines. Avian Dis., 44 (4), 968-976. http://dx.doi.org/10.2307/1593074

Barbour, E. K., Frerichs, W. N., Nabbut, N. H., Poss, P. E. \& Brinton M. K. (1993). Evaluation of bacterins containing three predominant phage types of Salmonella Enteritidis for prevention of infection in egg-laying chickens. Amer. J. Vet. Res., 54, 1306-1309.

Barrow, P. A. (1992). Further observations on the serological response to experimental Salmonella Typhimurium in chickens measured by ELISA. Epidemiol. Infect., 108(2), 231-241. http://dx.doi.org/10.1017/S0950268800049712

Barrow, P. A. (2000). The paratyphoid Salmonellae. Rev. Sci. Technol., 19, 351-375.

Barrow, P. A. (2007). Salmonella infections: Immune and non-immune protection with vaccines. Avian Pathol., 36 (1), 1-13. http://dx.doi.org/10.1080/03079450601113167

Barrow, P. A. \& Lovell, M. A. (1991). Experimental infection of egg laying hens with Salmonella Enteritidis phage type 4. Avian Pathol., 20, 335-348. http://dx.doi.org/10.1080/03079459108418769

Barrow, P. A., Lovell, M. A. \& Berchieri, A. (1990). Immunization of laying hens against Salmonella Enteritidis with live attenuated vaccines. Vet. Rec., 126 (10), 241-242.

Bielke, L.R., Elwood, A. L., Donoghue, D. J., Donoghue, A. M., Newberry, L. A., Neighbor, N. K. \& Hargis, B. M. (2003). Approach for selection of individual enteric bacteria for competitive exclusion in turkey poults. Poult. Sci., 82, 1378-1382.

Bjerrum, L., Engberg, R. M. \& Pedersen, K. (2003). Infection models for Salmonella typhimurium DT110 in day-old and 14-day-old broiler chickens kept in isolators. Avian Dis., 47, 1474-1480. http://dx.doi.org/10.1637/7051

Bogovic-Matijasic, B., Rogelj, I., Nes, I. F. \& Holo, H. (1998). Isolation and characterization of two bacteriocins of Lactobacillus acidophilus LF221. Appl. Microbiol. Biotechnol., 49, 606-612. http://dx.doi.org/10.1007/s002530051221

Bolder, N. M. \& Palmu, L. (1995). Effect of antibiotic treatment on competitive exclusion against Salmonella Enteritidis in broiler. Vet. Rec., 137, 350-351. http://dx.doi.org/10.1136/vr.137.14.350

British Veterinary Codes. (1970). Pharmaceutical Press, London.

Brown, S.L., Kiln, F. T. \& Jones, W. L. (1981). Safranin O stained antigen microagglutination test for detection of brucella antibodies. J. Clin. Microbiol., 13, 398-400.

Cavit, A. (2003). Effect of dietary probiotic supplementation on growth performance in the chickens. Turkish J. Vet. Anim. Sci., 28, 887-891.

Christensen, H. R., Frokiaer, H. \& Pestka, J. J. (2002). Lactobacilli differentially modulate expression of cytokines and maturation surface markers in murine dendritic cells. J. Immunol., 186, 171-178.

Cima, G. (2010). Vaccine use up since Salmonella outbreak. J. Amer. Vet. Med. Associ., 237 (12), 1356-1357.

Clifton-Hadley, F. A., Breslin, M., Venables, L. M., Sprigings, K. A., Cooles, S. W., Houghton, S. \& Woodward, M. J. (2002). A laboratory study of an inactivated bivalent iron restricted Salmonella Enteritidis and Typhimurium dual vaccine against $S$. Typhimurium challenge in chickens. Vet. Microbiol., 89 (2-3), 167-179. http://dx.doi.org/10.1016/S0378-1135(02)00169-4 
Coates, M.E. \& Fuller, R. (1977). The genotobiotic animal in the study of gut microbiology. Microbial ecology of the gut. Academic Press London, 153, 311-346.

Davies, R. \& Breslin, M. (2003). Effects of vaccination and other preventive methods for $S$. Enteritidis on commercial laying chicken farms. Vet. Rec., 153 (22), 673-677. http://dx.doi.org/10.1136/vr.153.22.673

Davies, R. \& Breslin, M. (2004). Observations on Salmonella contamination of eggs from infected commercial laying flocks where vaccination for $S$. Enteritidis had been used. Avian Pathol., 33, 135-146. http://dx.doi.org/10.1080/03079450310001652040

Davison, S., Benson, C. E., Henzler, D. J. \& Eckroade, R. J. (1999). Field observations with S. Enteritidis bacterins. Avian Dis., 43, 664-669. http://dx.doi.org/10.2307/1592735

Dekich, M. A. (1998). Broiler industry strategies for control of respiratory and enteric diseases. Poult. Sci., 77, 1176-1180.

Dorea, F.C., Cole, D. J., Hofacre, C., Zamperini, K., Mathis, D., Doyle, M. P., Lee, M. D. \& Maurer, J. J. (2010). Effect of vaccination of breeder chickens on contamination of broiler chicken carcasses in integrated poultry operations. Appl. Environ. Microbiol., 76 (23), 782-799. http://dx.doi.org/10.1128/AEM.01320-10

Fairchild, A. S., Grimes, J. L., Jones, F. T., Wineland, M. J., Edens, F. W. \& Sefteon, A. E. (2001). Effect of hen age, bio-MOS and flavomycin on poult susceptibility to oral Escherichia coli challenge. Poult. Sci., 80, 562-571.

Feberwee, A., de Vries, T. S., Elbers, A. R. \& de Jong, W. A. (2000). Results of a $S$. Enteritidis vaccination field trial in broiler-breeder flocks in the Netherlands. Avian Dis., 44, 249-255. http://dx.doi.org/10.2307/1592537

Feberwee, A., Hartman, E. G., de Wit, J. J. \& de Vries, T. S. (2001b). The spread of Salmonella Gallinarum 9R vaccine strain under field conditions. Avian Dis., 45, 1024-1029. http://dx.doi.org/10.2307/1592883

Feberwee, A., de Vries, T. S., Hartman, E. G., de Wit, J. J., Elbers, A. R. \& de Jong, W. A. (2001 a). Vaccination against $S$. Enteritidis in Dutch commercial layer flocks with a vaccine based on a live Salmonella Gallinarum 9R Strain: Evaluation of efficacy, safety and performance of serologic Salmonella tests. Avian Dis., 45, 83-91. http://dx.doi.org/10.2307/1593015

Fuller, R. (1997). The importance of lactobacilli in maintaining normal microbial balance in the crop. Br. Poult. Sci., 18, 85-94. http://dx.doi.org/10.1080/00071667708416332

Fulton, R.M., Nersessian B. N. \& Reed, W. M. (2002). Prevention of Salmonella Enteritidis infection in commercial ducklings by oral chicken egg-derived antibody alone or in combination with probiotics. Poult. Sci., 81,34-40.

Gast, R. K., Stone, H. D. \& Holt, P. S. (1993). Evaluation of the efficacy of oil-emulsion bacterins for reducing fecal shedding of $S$. Enteritidis by laying hens. Avian Dis., 37 (4), 1085-1091. http://dx.doi.org/10.2307/1591918

Ghosh, S. S. (1989). Comparative efficacy of four vaccines against $S$. Virchow in chicks in India. Res. Vet. Sci., $47,280-282$.

Goren, E., de Jong, W. A., Doornenbal, P., Bolder, N. M., Mulder, R. W. A. W. \& Hansen, J. (1988). Reduction of Salmonella infection in broilers by spray application of intestinal microflora: a longitudinal study. Vet. Q., 10, 249-255. http://dx.doi.org/10.1080/01652176.1988.9694181

Gracia, M. I., Engberg, R. M., Espinel, A. E., Cortes, M. \& Baucells, F. (2004). Bioefficacy of probiotics in broiler diets. Poult. Sci., 83 (suppl.1), 322.

Greenwood, P. E. \& Nikulin, M. S. (1996). A guide to Chi-Square testing. Wiley, New York.

Gurtler, M., Methner, U., Kobilke, H. \& Fehlhaber, K. (2004). Effect of orally administered egg yolk antibodies on Salmonella Enteritidis contamination of hen's eggs. J. Vet. Med., 51, 129-134. http://dx.doi.org/10.1111/j.1439-0450.2004.00739.x

Haider, M. G., Rahman, M. M., Hossain, M. M., Rashid, M., Sufian M. A., Islam, M. M. \& Haque, A. F. M. H. (2007). Production of formalin killed fowl typhoid vaccine using local isolates of Salmonella Gallinarum in Bangladesh. Bangladesh J. Vet. Med., 5 (1 \& 2), 33-38.

Havennarr, R. \& Huisinit, V. J. H. (1992). Probiotics: a general view. In: Wood, B. J. B. Editor The lactic acid bacteria in health and disease, Elsevier, New York, 1, 151-170. 
Helmick, C. G., Griffin, P. M., Addiss, D. G., Tauxe, R.V. \& Juranek, D. D. (1994). Infectious diarrheas. pp. 85-123 in Digestive Diseases in the United States: Epidemiology and Impact. J. E. Everhart, ed. Diane Publ. Co., Washington, DC.

Heres, L., Wagenaar, J. A., van Knapen, F. \& Urlings, B. A. P. (2003). Passage of Salmonella through the crop and gizzard of broiler chickens fed with fermented liquid feed. Avian Pathol., 32, 173-181. http://dx.doi.org/10.1080/0307945021000071597

Herikstad, H., Motarjemi, Y. \& Tauxe, R.V. (2002). Salmonella surveillance: A global survey of public health serotyping. Epidemiol. Infect., 219, 1-8.

Higgins, S. E., Erf, G. F., Higgins, J. P., Henderson, S. N., Wolfenden, D., Gaona-Ramirez, G. \& Hargis, B. M. $(2007 \mathrm{~b})$. Effect of probiotic treatment in broiler chicks on intestinal macrophage numbers and phagocytosis of Salmonella Enteritidis by abdominal exudate cells. Poult. Sci., 86 (11), 2315-2321. http://dx.doi.org/10.3382/ps.2007-00123

Higgins, J. P., Higgins, S. E., Salvador, V., Wolfenden, A. D., Tellez, G. \& Hargis, B. M. (2007 a). Temporal effects of lactic acid bacteria probiotic culture on Salmonella in neonatal broilers. Poult. Sci., 86, 1662-1666.

Higgins, J. P., Higgins, S. E., Guenther, K. L., Huff, W. E., Donoghue, A. M., Donoghue, D. J. \& Hargis, B. M. (2005). Use of a specific bacteriophage treatment to reduce Salmonella in poultry products. Poult. Sci., 84, $1141-1145$.

Hoop, R. K. (1997). The Swiss control programme for Salmonella Enteritidis in laying hens. Revista Sci. Technol. Inter. Epizitiol., 16, 885-890.

Huang, M. K., Chio, Y. J., Houde, R., Lee, J. W., Lee, B. \& Zhoo, X. (2004). Effects of lactobacilli and an acidophilic fungus on the production performance and immune response in broiler chickens. Poult. Sci., 38, 788-795.

Jarquin, R. L., Nava, G. M., Wolfenden, A. D., Donoghue, A. M., Hanning, I., Higgins, S. E. \& Hargis, B. M. (2007). The evaluation of organic acids and probiotic cultures to reduce Salmonella Enteriditis horizontal transmission and crop infection in broiler chickens. Inter. J. Poult. Sci., 6, 182-186. http://dx.doi.org/10.3923/ijps.2007.182.186

Jensen, B. B. (1998). The impact of feed additives on the microbial ecology of the gut in young pigs. J. Anim. Feed Sci., 7, 45-64.

Jin, L. Z., Ho, Y. W., Abdullah, N. \& Jalalaludin, S. (1997). Probiotics in poultry: Modes of action. World Poult. Sci., 53, 351-368. http://dx.doi.org/10.1079/WPS19970028

Jin, L. Z., Ho Y. W., Abdullah, N., Ali, M. A. \& Jalaludin, S. (1998). Note: lack of influence of adherent Lactobacillus isolates on the attachment of Escherichia coli to the intestinal epithelial cells of chicken in vitro. $J$. Appl. Microbiol., 84, 1171-1174. http://dx.doi.org/10.1046/j.1365-2672.1998.00434.x

Johanssen, S. A., Griffith, R. W., Wesley, I. V. \& Scanes, C. G. (2004). Salmonella enterica serovar typhimurium colonization of the crop in the domestic turkeys: Influence of probiotic and prebiotic treatment (Lactobacillus acidophilus and lactose). Avian Dis., 48, 279-286. http://dx.doi.org/10.1637/7092

Kabir, S. M. L., Rahman, M. M., Rahman, M. B. \& Ahmed, S. U. (2004). The dynamics of probiotics on growth performance and immune response in broilers. Inter. J. Poult. Sci., 3, 361-365. http://dx.doi.org/10.3923/ijps.2004.361.364

Kalavathy, R., Abdullah, N., Jalaludin, S. \& Ho, Y. W. (2003). Effects of lactobacillus cultures on growth performance, abdominal fat deposition, serum lipids and weight of organs of broiler chickens. Br. Poult. Sci., 44, 139-144. http://dx.doi.org/10.1080/0007166031000085445

Khan, M. I., Fadl, A. A. \& Venkitanarayanan, K. S. (2003). Reducing colonization of $S$. Enteritidis in chickens by targeting outer membrane proteins. J. Appl. Microbiol., 95, 142-145. http://dx.doi.org/10.1046/j.1365-2672.2003.01953.x

Kim, C. J., Nagraja, K.V. \& Pomeroy, B. S. (1991). Enzyme linked immunosorbant assay for detection of $S$. Enteritidis infection in chickens. Amer. J. Res., 52 (7), 1069-1074.

Koenen, M. E., Karmer, J., van der Hulst, R., Heres, L., Jeurissen, S. H. \& Boersma, W. J. (2004). Immunomodulation by probiotic lactobacilli in layer and meat type chickens. Br. Poult. Sci., 45, 355-366. http://dx.doi.org/10.1080/00071660410001730851 
Lee, S., Lillehoj, H. S., Dalloul, R. A., Park, D. W., Hong, Y. H. \& Lin, J. J. (2007). Influence of Pediococcus-based probiotic on coccidiosis in broliler chickens. Poult. Sci., 86, 63-66.

Lillehoj, E. P., Yun, C. H. \& Lillehoj, H. S. (2000). Vaccines against the avian enteropathogens Eimeria, Cryptosporidium and Salmonella. Anim. Hlth Res. Rev., 1 (1), 47-65. http://dx.doi.org/10.1017/S1466252300000050

Lister, S. A. (1988). Salmonella Enteritidis infection in broilers and broiler breeders. Vet. Rec., 123, 350. http://dx.doi.org/10.1136/vr.123.13.350

Liu, W., Yang, Y., Chung, N. \& Kwang, J. (2001). Induction of humoral immune response and protective immunity in chickens against $S$. Enteritidis after a single dose of killed bacterium-loaded microspheres. Avian Dis., 45, 797-806. http://dx.doi.org/10.2307/1592859

Mayrhofer, S., Paulsen, P., Smulders, F. J. M. \& Hilbert, F. (2003). Antimicrobial resistance profile of five major food-borne pathogens isolated from beef, pork and poultry. Inter. J. Food Microbiol., 97 (1), 23-29. http://dx.doi.org/10.1016/j.ijfoodmicro.2004.04.006

Meed, G. C. (2000). Prospects for competitive exclusion treatment to control Salmonellas and other food borne pathogens in poultry. Vet. J., 159, 111-123. http://dx.doi.org/10.1053/tvjl.1999.0423

Methner, U. \& Steinbach, G. (1997). Efficacy of maternal Salmonella antibodies against oral infection of chicks with Salmonella Enteritidis. Berlin Münch. Tierärztl. Wschr., 110, 373-377.

Methner, U., Steinbach, G., Meyer, H. (1994). Investigations on the efficacy of Salmonella immunization of broiler breeder birds to Salmonella colonization of these birds and their progeny following experimental oral infection. Berlin Münch. Tierärztl. Wschr., 107, 192-198.

Methner, U., Barrow, P. A., Berndt, A. \& Rychlik, I. (2011). Salmonella Enteritidis with double deletion in phoPfliC-A potential live Salmonella vaccine candidate with novel characteristics for use in chickens. Vaccine, $24,1-5$.

Midilli, M. M., Kocabaglı, N., Muglalı, O. H., Turan, N., Ylmaz, B. \& Çakır, S. (2009). Effects of dietary probiotic and prebiotic supplementation on growth performance and serum IgG concentration of broilers. South African J. Anim. Sci., 38 (1), 54-59.

Miyamoto, T., Kitaoka, D., Withanage, G., Fukata, T., Sasai, K. \& Baba, E. (1999). Evaluation of the efficacy of $S$. Enteritidis oil-emulsion bacterin in an intravaginal challenge model in hens. Avian Dis., 43, 497-505. http://dx.doi.org/10.2307/1592648

Mohan, B., Kadirvel, R., Natarajan, A. \& Bhaskaran, M. (1996). Effect of probiotic supplementation on growth, nitrogen utilization and serum cholesterol in broilers. Br. Poult. Sci., 37, 395-401. http://dx.doi.org/10.1080/00071669608417870

Mohrah, I. M. \& Zaki, M. M. (1995). Trails to prepare potent vaccine against Salmonella Gallinarum Pullorum infection. Vet. Med. J., 43, 97-102.

Moore, R. W., Byrd, J. A., Knape, K. D., Anderson, R. C., Callaway, T. R., Edrington, T., Kubena, L. F. \& Nisbet, D. J. (2006). The effect of an experimental chlorate product on Salmonella recovery of turkeys when administered prior to feed and water withdrawal. Poult. Sci., 85, 2101-2105.

Murugkar, H.V., Rahman, H. \& Dutta, P. K. (2005). Distribution of virulence genes in Salmonella serovars isolated from man and animals. Indian Med. Res., 177, 66-70.

Nahashon, S. N., Nakaue, H. S. \& Mirosh, L.W. (1992). Effect of direct-fed microbials on nutrient retention and production parameters of laying pullets. Poult. Sci., 71 (Suppl.1), 111.

Nakamura, M., Nagamine, N., Takahashi, T., Suzuki, S. \& Sato, S. (1994). Evaluation of the efficacy of a bacterin against $S$. Enteritidis infection and the effect of stress after vaccination. Avian Dis., 38, 717-724. http://dx.doi.org/10.2307/1592106

Nakamura, M., Nagata, T., Okamura, S., Takehara, K. \& Holt, P. S. (2004). The effect of killed Salmonella Enteritidis vaccine prior to induced molting on the shedding of $S$. Enteritidis in laying hens. Avian Dis., 48, 183-188. http://dx.doi.org/10.1637/7040

National Research Council (1984). Nutrient requirement of poultry. $8^{\text {th }}$ Rev. Ed. National Academy Press, Washington DC. 
Nisbet, D. J., Corrier, D. E., Ricke, S. C., Hume, M. E., Byrdii, J. A. \& de Loach, J. R. (1996). Maintenance of the biological efficacy in chicks of a caecal competitive exclusion culture against Salmonella by continuous-flow fermentation. J. Food Prot., 59, 1279-1283.

O'Brien, J. D. P. (1988). Salmonella Enteritidis infection in broiler chickens. Vet. Rec., 8, 214-218. http://dx.doi.org/10.1136/vr.122.9.214-b

Ocan, V. S., de Ruiz Holgado, A. A. \& Nader-Macias, M. E. (1999). Characterization of a bacteriocin-like substance produced by a vaginal Lactobacillus salivarius strain. Appl. Environ. Microbiol., 65, 5631-5635.

Okamoto, A. S., Andreatti Filho, R. L., Lima, E. T., Pereira, R. E. P., Menconi, A., Rocha, T. S. \& Marietto-Gonçalves, G. A. (2007). Immunological evaluation of the intestinal mucosa of broiler chicks treated with lactobacillus spp. and challenged with Salmonella Enteritidis. Brazilian J. Poult. Sci., 9 (4), 259-262.

Okamura, H., Lillehoj, S., Raybourne, R. B., Babu, U. \& Heckert, R. (2003). Antigen-specific lymphocyte proliferation and interleukin production in chickens immunized with killed $S$. Enteritidis vaccine experimental subunit vaccines. Avian Dis., 47 (4), 1331-1338. http://dx.doi.org/10.1637/6096

Okamura, H., Lillehoj, S., Raybourne, R. B., Babu, U. \& Heckert, R. (2004). Cell-mediated immune responses to a killed Salmonella Enteritidis vaccine: lymphocyte proliferation, T-cell changes and interleukin-6 (IL-6), IL-1, IL-2, and IFN- [gamma] production. Comp. Immunol. Microbiol. Infect. Dis., 27, 255-272. http://dx.doi.org/10.1016/j.cimid.2003.12.001

Olabisi, O. I. \& Peter, S. (2008). Salmonella Enteritidis experimental infection in chickens: Effects of challenge dose on serum immunoglobulin G antibody response. African J. Biotechnol., 7 (20), 3783-3787.

Opalinski, M., Maiorka, A., Dahlke, F., Cunha, F., Vargas, F. S. C. \& Cardozo, E. (2007). On the use of a probiotic (Bacillus subtilis - strain DSM 17299) as growth promoter in broiler diets. Brazilian J. Poult. Sci., 9 (2), 99-103.

Paiva, J. B., Penha, F., Amguello, Y. M. S., Siva, M. D., Gardin, Y., Resende, F., Berchieri, A. \& Sestsi, L. (2009). Efficacy of several Salmonella vaccination programme against experimental challenge with Salmonella Gallinarum in commercial brown breeder hens. Brazilian J. Poult. Sci., 11 (1), 65-72.

Pakpinyo, S., Yong, M. \& Lertruangpunyawuti, V. (2008). Efficacy of Salmonella Typhimurium (ST) live vaccine and $S$. Enteritidis inactivated vaccine against $S$. Enteritidis in layer chickens. Proc. $15^{\text {th }}$ Cong. FAVA 27-30 October FAVA-OIE Joint Symp. Emerg. Dis., Bangkok, Thailand. pp 153.

Panda, A. K., Reddy, M. R., Ramarao, S. V. \& Praharaj, N. K. (2000). Effect of dietary supplementation of probiotic on performance and immune response of layers in decline phase of production. Indian J. poult. Sci., 35, 102-104.

Pascual, M., Hugas, M., Badiola, J. I., Monfort, J. M. \& Garriga, M. (1999). Lactobacillus salivarius CC2197 prevents Salmonella Enteritidis colonization in chickens. Appl. Environ. Microbiol., 65, 4981-4986.

Patterson, J. \& Burkholder, K. (2003). Application of prebiotics and probiotics in poultry production. Poult. Sci., 82, 627-631.

Penha, F. R. A., de Paiva, J. B., de Silva, M. D., de Almieda, A. M. \& Berchieri, A. Jr. (2010). Control of Salmonella Enteritidis and Salmonella Gallinarum in birds by using live vaccine candidate containing attenuated Salmonella Gallinarum mutant strain. Vaccine, 28, 2853-2859. http://dx.doi.org/10.1016/j.vaccine.2010.01.058

Penha, F. R. A., de Paiva, J. B., Arguello, Y. M., de Silva, M. D., Gardin, Y., Resende, F., Berchieri, A. Jr. \& Sesti, L. (2009). Efficacy of several vaccination programmes in commercial layer and broiler breeder hens against experimental challenge with Salmonella enterica serovar Enteritidis. Avian Pathol., 38 (5), 367-375. http://dx.doi.org/10.1080/03079450903183645

Piao, Z., Toyota-Hanatani, Y., Ohta, H., Sasai, K., Tani, H. \& Baba, E. (2007). Effects of Salmonella enterica subsp. enterica serovar Enteritidis vaccination in layer hens subjected to $S$. Enteritidis challenge and various feed withdrawal regimens. Vet. Microbiol., 125, 111-119. http://dx.doi.org/10.1016/j.vetmic.2007.05.008

Pollmann, D. S., Danielson, D. M. \& Peo, E. R. (1980). Effect of microbial additives on performance of starter and growing finishing pigs. J. Anim. Sci., 51, 577-581.

Priyantha, M. A. R. (2009). An overview: vaccination to control fowl typhoid in commercial layers. Wild J. Anim. Sci., 52, 53-56. 
Radwan, H.M. (2007). Studies on Salmonella infection in chicken flocks. Master Vet. Sci. Thesis, Fac. of Vet. Med., Dept. Avian and Aquatic Anim. Med., Alex. Univ., Egypt.

Rahimi, S., Moghadam Shiraz, Z., Zahraei Salehi, T., Karimi Torshizi, M. A. \& Grimes, J. L. (2007). Prevention of Salmonella infection in poultry by specific egg-derived antibody. Inter. J. Poult. Sci., 6 (4), 230-235. http://dx.doi.org/10.3923/ijps.2007.230.235

Revolledo, L., Ferreira, C. S. A. \& Ferreira, A. J. P. (2009). Prevention of Salmonella Typhimurium colonization and organ invasion by combination treatment in broiler chicks. Poult. Sci., 88, 734-743. http://dx.doi.org/10.3382/ps.2008-00410

Riemann, H., Himathongkham, S., Willoughby, D., Tarbell, R. \& Breitmeyer, R. (1998). A survey for Salmonella by drug swabbing manure piles in California egg ranches. Avian Dis., 42 (1), 67-71. http://dx.doi.org/10.2307/1592577

Rolfe, R. D. (2000). The role of probiotic cultures in the control of gastrointestinal health. J. Nutr., 130, 396-402.

Rowghani, E., Arab, M. \& Akbarian, A. (2007). Effects of a probiotic and other feed additives on performance and immune response of broiler chicks. Inter. J. Poult. Sci., 6, 261-265. http://dx.doi.org/10.3923/ijps.2007.261.265

Saarela, M., Mogensen, G., Fondens, R., Matto, J. \& Mattila-Sandholm, T. (2000). Probiotic bacteria: safety, functional and technological properties. $J$. Biotechnol., 84, 197-215. http://dx.doi.org/10.1016/S0168-1656(00)00375-8

Sainsbury, D. (1984). Systems of management. Ch.9 P.102. In Poultry Health and Management. $2^{\text {nd }} E d . B y$ Sainsbury. Granada Publishing LTD. 8 Grafton Street, London WIX3 LA.

Samanta, M. \& Biswas, P. (1995). Effect of feeding probiotic and lactic acid on the performance of broiler. Indian J. Poult. Sci., 30, 145-147.

Seo, K. H., Holt, P. S., Gast, R. K. \& Hofacre, C. L. (2000). Elimination of early Salmonella Enteritidis infection after treatment with competitive exclusion culture and enrofloxacin in experimentally infected chicks. Poult. Sci., $79,1408-1413$.

Seuna, E., Schneitz, C., Nurmi, E. \& Makela, P. H. (1980). Combined therapy of Salmonella infection in chickens by antimicrobial agents followed by culture caecal bacteria. Poult. Sci., 59, 1187-1192.

Sevage, T. F., Cotter, P. F. \& Zakrzewska, E. I. (1996). The effect of feeding of mannan-oligosacharide on immunoglobulins, plasma IgG and bile IgA of wrolstad MW male turkeys. Poult. Sci., 75 (Suppl. 1), 143 (Abstract).

Shoeib, H. K., Sayed, A. N., Sotohy, S. A. \& Abdel Ghaffar, S. K. (1997). Response of broiler chicks to probiotic (pronifer) supplementation. Assiut Vet. Med. J., 36, 103-116.

Shott, S. (1990). Statistical for health professionals. W.B. Saunders Co. Philadelphia, 313-336.

Soerjadi, A. S., Stehman, S. M., Snoeyenbos, G. H., Weinack, O. M. \& Smyser, C. F. (1981). The influence of lactobacilli on the competitive exclusion of paratyphoid Salmonellae in chickens. Avian Dis., 25, 1027-1033. http://dx.doi.org/10.2307/1590078

Soomro, A. H., Masud, T. \& Rathore, H. A. (2002). Application of probiotic culture. J. Amer. Vet. Advances, 1, $40-42$.

Starvic, S. (1992). Defined cultures and prospects. Inter. J. Food Microbiol., 15, 245-263. http://dx.doi.org/10.1016/0168-1605(92)90056-9

Tellez, G., Petrone, V. M., Escorcia, M., Morishita, T. Y., Cobb, C. W. \& Villasenor, L. (2001). Evaluation of avian-specific probiotic and Salmonella Enteritidis, Salmonella Typhimurium, and Salmonella Heidelberg-specific antibodies on cecal colonization and organ invasion of Salmonella Enteritidis in broilers. $J$. Food Prot., 64, 287-291.

Timmerman, H. M., Veldman, A., van den Elsen, E., Rombouts, F. M. \& Beynen, A. C. (2006). Mortality and growth performance of broilers given drinking water supplemented with chicken-specific probiotics. Poult. Sci., $85,1383-1388$.

Timms, L. M., Marshall, R. N. \& Breslin, M. F. (1990). Laboratory assessment of protection given by an experimental $S$. Enteritidis PT4 inactivated adjuvant vaccine. Vet. Rec., 127 (25-26), 611-614. 
Timms, L. M., Marshall, R. N. \& Breslin, M. F. (1994). Laboratory and field trial assessment of protection given by a $S$. Enteritidis PT4 inactivated adjuvant vaccine. Br. Vet. J., 150 (1), 93-102.

Toms, C. \& Powvie, F. (2001). Control of intestinal inflammation by regulatory T cells. Microb. Infect., 3 , 929-935. http://dx.doi.org/10.1016/S1286-4579(01)01454-X

Tran, T. Q., Quessy, S., Letellier, A., Desrosiers, A. \& Boulianne, M. (2010). Immune response following vaccination against Salmonella Enteritidis using 2 commercial bacterins in laying hens. Canad. J. Vet. Res., 74 (3), 185-192.

Van Belle, M. (2001). Current status and future perspectives in EU for antibiotics, probiotics, enzymes and organic acids in nutrition. In: Gut environment of pigs. Ed. Piva, A., Bachkniudsen, K. E. and Lindberg, J. E., 231-256.

Vicente, J. L., Aviña, L., Torres-Rodriguez, A., Hargis, B. \& Tellez, G. (2007 a). Effect of a Lactobacillus spp. based probiotic culture product on broiler chicks performance under commercial conditions. Inter. J. Poult. Sci., 6, 154-156. http://dx.doi.org/10.3923/ijps.2007.154.156

Vicente, J. L., Wolfenden, A., Torres-Rodriguez, A., Higgins, S., Tellez, G. \& Hargis, B. M. (2007 b). Effect of probiotic culture candidates on Salmonella prevalence in commercial turkey houses. J. Appl. Poult. Res., 16, $55-58$.

Vugia, D. J., Mishu, B., Smith, M., Travris, D. R., Hickman Brenner, F. W. \& Taux, R. V. (1993). Salmonella Enteritidis outbreak in a restaurant chain: The continuing challenge of prevention. Epidemiol. Infect., 110, 49-61. http://dx.doi.org/10.1017/S0950268800050676

Wafaa, A. A., Madian, K., Ebtehal, A. \& Gehan, M. K. (2006). The effect of combined competitive exclusion culture with mannan-oligosacharides and ciprofloxacin on Salmonella Enteritidis colonization in broiler chickens. $12^{\text {th }}$ Cong. Fac. Vet. Med., Assiut Univ., Egypt.

Wilkie, D. C. (2006). Non-antibiotic approaches to control pathogens in the gastrointestinal tract of the broiler chicken. Ph. D. Thesis, College of Graduate Studies and Research in Partial Fulfilment of the Requirements.

Williams, E. \& Whittemore, A. D. (1971). Serological diagnosis of pullorum disease with the micro-agglutination system. Appl. Microbiol., 21 (3), 394-399.

Wolfenden, A. D., Vicente, J. L., Higgins, J. P., Andreatti, R., Higgins, S. E., Hargis, B. M. \& Tellez, G. (2007). Effect of organic acids and probiotics on Salmonella Enteritidis infection in broiler chickens. Inter. J. Poult. Sci., 6, 403-405. http://dx.doi.org/10.3923/ijps.2007.403.405

Woodward, M. J., Gettinby, G., Breslin, M. F., Corkish, J. D. \& Houghton, S. (2003). The efficacy of Salenvac, a Salmonella enterica subsp. enterica serotype Enteritidis iron-restricted bacterin vaccine, in laying chickens. Avian Pathol., 31, 383-392. http://dx.doi.org/10.1080/03079450220141660

Wray, C., Davies, R. H. \& Corkish, J. D. (1996). Enterobacteriaceae. In Poultry Diseases, $4^{\text {th }}$ ed.; Jordan, T. W., Pattison, M., Eds.; W. B. Saunders: Philadelphia, PA, USA, pp. 9-43.

Young, J. L. \& Kang, M. S. (2005). Safety and efficacy of Salmonella Gallinarum 9R vaccine in young laying chickens. Avian Pathol., 34 (4), 362-366. http://dx.doi.org/10.1080/03079450500180895

Young, S. D., Olusanya, O., Jones, K. H., Liu, T., Liljebjelke, K. A. \& Hofacre, C. L. (2007). Salmonella incidence in broilers from breeders vaccinated with live and killed Salmonella. J. Appl. Poult. Res., 16, 521-528. http://dx.doi.org/10.3382/japr.2007-00009

Zhang-Barber, L., Turner, A. K. \& Barrow, P. A. (1999). Vaccination for control of Salmonella in poultry. Vaccine, 17, 2538-2545. http://dx.doi.org/10.1016/S0264-410X(99)00060-2

Zulkifli, I., Abdullah, N., Azirin, N. \& Mchal, H. T. W. (2000). Growth performance and immune response of two commercial broiler strains fed diets containing lactobacillus cultures and oxytetracycline under heat stress conditions. Br. Poult. Sci., 41, 593-597. http://dx.doi.org/10.1080/713654979 
Table 1 . The protection rate of the locally prepared inactivated $S$. Enteritidis bacterin and the probiotic treatment against $S$. Enteritidis infection in broiler chickens

\begin{tabular}{|c|c|c|c|c|c|c|c|c|}
\hline \multirow{2}{*}{ Groups } & \multirow{2}{*}{$\begin{array}{c}\text { Total } \\
\text { No. } \\
\text { of } \\
\text { birds }\end{array}$} & \multicolumn{3}{|c|}{$\begin{array}{c}\text { No. of dead birds/week post } \\
\text { challenge }\end{array}$} & \multirow{2}{*}{$\begin{array}{l}\text { Total No. of } \\
\text { dead birds }\end{array}$} & \multirow{2}{*}{$\begin{array}{l}\text { Mortality } \\
\text { rate }\end{array}$} & \multirow{2}{*}{$\begin{array}{c}\text { Total No. of } \\
\text { survived birds }\end{array}$} & \multirow{2}{*}{ Protection \% } \\
\hline & & $\begin{array}{c}1^{\text {st }} \\
\text { week }\end{array}$ & $\begin{array}{c}2^{\text {nd }} \\
\text { week }\end{array}$ & $\begin{array}{c}3^{\text {rd }} \\
\text { week }\end{array}$ & & & & \\
\hline Blank control & 75 & 0 & 0 & 0 & 0 & 0 & 75 & $100^{\mathrm{a}}$ \\
\hline $\begin{array}{c}\text { Infected, } \\
\text { non-treated }\end{array}$ & 75 & 17 & 5 & 1 & 23 & 30.67 & 52 & $0^{\mathrm{d}}$ \\
\hline $\begin{array}{l}\text { Vaccinated, } \\
\text { Infected }\end{array}$ & 75 & 3 & 1 & 0 & 4 & 5.33 & 71 & $82.61^{\mathrm{b}}$ \\
\hline $\begin{array}{c}\text { Probiotic treated, } \\
\text { Infected }\end{array}$ & 75 & 6 & 3 & 0 & 9 & 12 & 66 & $60.87^{\mathrm{c}}$ \\
\hline
\end{tabular}

Protection rate $=$

\section{Survived test-survived control positive}

Dead control positive

*Different letters within the same column were significantly difference at $(P \leq 0.05)$.

Table 2. The faecal shedding rate of $S$. Enteritidis in broiler chickens after vaccination with the locally prepared bacterin and treatment with probiotic

\begin{tabular}{|c|c|c|c|c|c|c|c|c|}
\hline \multirow{3}{*}{ Treatment group } & \multicolumn{6}{|c|}{ Weeks post challenge } & \multirow{3}{*}{$+\mathrm{Ve} /$ Total } & \multirow{3}{*}{$\%$} \\
\hline & \multicolumn{2}{|c|}{$1^{\mathrm{st}} \mathrm{wk}$} & \multicolumn{2}{|c|}{$2^{\mathrm{st}} \mathrm{wk}$} & \multicolumn{2}{|c|}{$3^{\text {st }} \mathrm{wk}$} & & \\
\hline & $+\mathrm{Ve} /$ Total & $\%$ & $+\mathrm{Ve} /$ Total & $\%$ & $+\mathrm{Ve} /$ Total & $\%$ & & \\
\hline Blank control & $0 / 75$ & $0^{\mathrm{Ad}}$ & $0 / 75$ & $0^{\mathrm{Ad}}$ & $0 / 75$ & $0^{\mathrm{Ad}}$ & 0 & $0^{\mathrm{d}}$ \\
\hline Infected, non-treated & $30 / 58$ & $51.72^{\mathrm{Aa}}$ & $16 / 43$ & $37.2^{\mathrm{Ba}}$ & $8 / 32$ & $25^{\mathrm{Ca}}$ & $54 / 133$ & $40.6^{\mathrm{a}}$ \\
\hline Vaccinated, Infected & $13 / 72$ & $18.06^{\mathrm{Ac}}$ & $4 / 61$ & $6.56^{\mathrm{Bc}}$ & $0 / 51$ & $0^{\mathrm{Cc}}$ & $17 / 184$ & $\underset{\mathrm{c}}{9.24}$ \\
\hline $\begin{array}{c}\text { Probiotic treated, } \\
\text { Infected }\end{array}$ & $18 / 69$ & $26.08^{\mathrm{Ab}}$ & $10 / 56$ & $17.86^{\mathrm{Bb}}$ & $2 / 46$ & $4.35^{\mathrm{Cb}}$ & $30 / 171$ & $17.5^{\mathrm{b}}$ \\
\hline
\end{tabular}

$+V e=$ Positive birds

Different small letters within the same column were significantly difference at $(P \leq 0.05)$.

Different capital letters within the same row were significantly difference at $(P \leq 0.05)$. 
Table 3. The re-isolation rate of S. Enteritidis from different organs of sacrificed broiler chickens after vaccination with the locally prepared bacterin and treatment with probiotic

\begin{tabular}{|c|c|c|c|c|c|c|c|c|c|c|c|c|c|c|c|c|}
\hline \multirow{4}{*}{ Group } & \multicolumn{15}{|c|}{ Re-isolation rate } & \multirow{4}{*}{ Total } \\
\hline & \multicolumn{5}{|c|}{ At the end of $1^{5 t} \mathrm{Wk}$ post challenge } & \multicolumn{5}{|c|}{ At the end of $2^{\text {sd }} \mathrm{Wk}$ post challenge } & \multicolumn{5}{|c|}{ At the end of $3^{\text {rd }} \mathrm{Wk}$ post challenge } & \\
\hline & \multicolumn{15}{|c|}{ Examined Organs } & \\
\hline & Liver & Heart & Spleen & Cecum & Total & Liver & Heart & Spleen & Cecum & Total & Liver & Heart & Spleen & Cecrum & Total & \\
\hline Blank control & 0 & 0 & 0 & 0 & $0 \% \%^{d}$ & 0 & 0 & 0 & 0 & $0 \% \%^{d}$ & 0 & 0 & 0 & 0 & $0 \% \%^{d}$ & $0 \% 6^{d}$ \\
\hline Infected, non-treated & $7 / 10$ & $5 / 10$ & $6 / 10$ & $8 / 10$ & $\begin{array}{l}26 / 40 \\
65 \% \%^{4}\end{array}$ & $4 / 10$ & $4 / 10$ & $5 / 10$ & $6 / 10$ & $\begin{array}{r}19 / 40 \\
47.5 \%^{\mathrm{Ba}}\end{array}$ & $2 / 10$ & $1 / 10$ & $4 / 10$ & $4 / 10$ & $\begin{array}{l}11 / 40 \\
27.5 \% \%^{\mathrm{cs}}\end{array}$ & $\begin{array}{c}56 / 120 \\
46.67 \% \%^{2}\end{array}$ \\
\hline $\begin{array}{l}\text { Vaccinated, Infected } \\
\text { group }\end{array}$ & $2 / 10$ & $2 / 10$ & $2 / 10$ & $3 / 10$ & $\begin{array}{c}9 / 40 \\
22.5 \% \%^{k}\end{array}$ & $1 / 10$ & $0 / 10$ & $1 / 10$ & $2 / 10$ & $\begin{array}{c}4 / 40 \\
10 \% \%^{\mathrm{Bc}}\end{array}$ & $0 / 10$ & $0 / 10$ & $0 / 10$ & $1 / 10$ & $\begin{array}{r}1 / 40 \\
2.5 \% \mathrm{C}^{\mathrm{Ce}}\end{array}$ & $\begin{array}{l}14 / 120 \\
11.67^{\circ}\end{array}$ \\
\hline $\begin{array}{l}\text { Probiotic treated, } \\
\text { Infected group }\end{array}$ & $3 / 10$ & $2 / 10$ & $3 / 10$ & $4 / 10$ & $\begin{array}{l}12 / 40 \\
30 \% * 6\end{array}$ & $\mid 3 / 10$ & $2 / 10$ & $2 / 10$ & $3 / 10$ & $\begin{array}{l}10 / 40 \\
25 \% \%^{\circ b}\end{array}$ & $1 / 10$ & $0 / 10$ & $1 / 10$ & $2 / 10$ & $\begin{array}{c}4 / 40 \\
10 \% \%^{86}\end{array}$ & $\begin{array}{c}26 / 120 \\
21.67 \%\end{array}$ \\
\hline
\end{tabular}

Different small letters within the same column were significantly difference at $(P \leq 0.05)$

Different capital letters within the same row were significantly difference at $(P \leq 0.05)$

Table 4. Average body weight, cumulative feed conversion and European Production Efficiency Factor in broiler chickens after vaccination with the locally prepared S. Enteritidis bacterin and treatment with probiotic

\begin{tabular}{|c|c|c|c|c|c|c|c|c|}
\hline \multirow{4}{*}{$\begin{array}{c}\text { Treatment } \\
\text { group }\end{array}$} & \multicolumn{6}{|c|}{ Average body weight/g } & \multirow{4}{*}{ CFC } & \multirow{4}{*}{$\mathrm{EPEF}^{* *}$} \\
\hline & \multicolumn{6}{|c|}{ Age/week } & & \\
\hline & \multicolumn{3}{|c|}{ Before challenge } & \multicolumn{3}{|c|}{ After challenge } & & \\
\hline & 1 & 2 & 3 & 4 & 5 & 6 & & \\
\hline Blank control & $133.40 \pm 6.30^{\mathrm{a}}$ & $291.1 \pm 5.21^{\mathrm{a}}$ & $563.75 \pm 11.86^{b}$ & $744.12 \pm 24.77^{b}$ & $984.1 \pm 42.21^{b}$ & $1580.2 \pm 65.22^{\mathrm{b}}$ & 2.03 & 189.12 \\
\hline $\begin{array}{l}\text { Infected, non- } \\
\text { treated }\end{array}$ & $128.11 \pm 5.31^{\mathrm{a}}$ & $290.1 \pm 8.679^{a}$ & $501.1 \pm 18.0^{\circ}$ & $699.22 \pm 19.63^{\mathrm{c}}$ & $801.50 \pm 13.50^{c}$ & $1355.1 \pm 54.10^{c}$ & 2.43 & 148.25 \\
\hline $\begin{array}{l}\text { probiatic } \\
\text { treated, } \\
\text { Infected. }\end{array}$ & $130.43 \pm 3.62^{\mathrm{a}}$ & $288.2 \pm 9.90^{\mathrm{a}}$ & $599.1 \pm 21.8^{\mathrm{a}}$ & $810.8 \pm 21.3^{\mathrm{a}}$ & $1100.1 \pm 55.3^{\mathrm{a}}$ & $1705 \pm 21.50^{a}$ & 1.78 & 213.44 \\
\hline $\begin{array}{l}\text { Vaccinated, } \\
\text { Infected. }\end{array}$ & $134.73 \pm 2.77^{\mathrm{a}}$ & $293.1 \pm 8.7^{\mathrm{a}}$ & $589.1 \pm 18.21^{\mathrm{ab}}$ & $799.90 \pm 12.10^{\mathrm{ab}}$ & $1005.0 \pm 71.00^{\mathrm{ab}}$ & $1640.1 \pm 55.91^{\mathrm{ab}}$ & 1.89 & 205.44 \\
\hline LSD & 16.45 & 25.2 & 30.1 & 63.48 & 115.80 & 119.75 & & \\
\hline
\end{tabular}

CFC $=$ Cumulative feed conversion

$\mathrm{EPEF}^{*}=$ European Production Efficiency Factor. The higher the value, the better the performance

LSD=Least significant difference as determined by Fisher's protected LSD procedures

*Means within the column with different letters are significantly different $(p \leq 0.05)$ 
Table 5. Microagglutination antibody titers in the sera of broiler chickens after vaccination with locally prepared S. Enteritidis bacterin and treatment with probiotic

\begin{tabular}{|c|c|c|c|c|c|c|c|c|c|c|c|c|}
\hline \multirow[t]{2}{*}{ Age/day } & \multirow[t]{2}{*}{ Interval } & \multirow[t]{2}{*}{ Group } & \multirow{2}{*}{$\begin{array}{l}\text { No. of tested } \\
\text { samples }\end{array}$} & \multicolumn{8}{|c|}{$\begin{array}{l}\text { Antibody titers of chicken } \\
\text { at different serial dilutions }\end{array}$} & \multirow[t]{2}{*}{ GMT } \\
\hline & & & & 0 & 20 & 40 & 80 & 160 & 320 & 640 & 1280 & \\
\hline \multirow{4}{*}{1} & \multirow{4}{*}{$\begin{array}{c}\text { Before } 1^{\text {st }} \\
\text { vaccination dose }\end{array}$} & G1 & 10 & 10 & 0 & 0 & 0 & 0 & 0 & 0 & 0 & 0 \\
\hline & & G2 & 10 & 10 & 0 & 0 & 0 & 0 & 0 & 0 & 0 & 0 \\
\hline & & G3 & 10 & 10 & 0 & 0 & 0 & 0 & 0 & 0 & 0 & 0 \\
\hline & & G4 & 10 & 10 & 0 & 0 & 0 & 0 & 0 & 0 & 0 & 0 \\
\hline \multirow{4}{*}{10} & \multirow{4}{*}{$\begin{array}{c}\text { Before booster } \\
\text { vaccination dose }\end{array}$} & G1 & 10 & 10 & 0 & 0 & 0 & 0 & 0 & 0 & 0 & 0 \\
\hline & & G2 & 10 & 10 & 0 & 0 & 0 & 0 & 0 & 0 & 0 & 0 \\
\hline & & G3 & 10 & 0 & 0 & 3 & 7 & 0 & 0 & 0 & 0 & 65 \\
\hline & & G4 & 10 & 0 & 0 & 4 & 6 & 0 & 0 & 0 & 0 & 60.6 \\
\hline \multirow{4}{*}{20} & \multirow{4}{*}{ Before challenge } & G1 & 10 & 10 & 0 & 0 & 0 & 0 & 0 & 0 & 0 & 0 \\
\hline & & $\mathrm{G} 2$ & 10 & 10 & 0 & 0 & 0 & 0 & 0 & 0 & 0 & 0 \\
\hline & & G3 & 10 & 0 & 0 & 0 & 8 & 1 & 1 & 0 & 0 & 98 \\
\hline & & G4 & 10 & 0 & 0 & 2 & 7 & 1 & 0 & 0 & 0 & 74.5 \\
\hline \multirow{4}{*}{27} & \multirow{4}{*}{$\begin{array}{l}1^{\text {st }} \text { week post } \\
\text { challenge }\end{array}$} & G1 & 10 & 10 & 0 & 0 & 0 & 0 & 0 & 0 & 0 & 0 \\
\hline & & G2 & 10 & 0 & 0 & 4 & 6 & 0 & 0 & 0 & 0 & 60.6 \\
\hline & & G3 & 10 & 0 & 0 & 0 & 0 & 7 & 2 & 1 & 0 & 211.1 \\
\hline & & G4 & 10 & 0 & 0 & 2 & 1 & 7 & 0 & 0 & 0 & 113.1 \\
\hline \multirow{4}{*}{34} & \multirow{4}{*}{$\begin{array}{c}2^{\text {nd }} \text { week post } \\
\text { challenge }\end{array}$} & G1 & 10 & 10 & 0 & 0 & 0 & 0 & 0 & 0 & 0 & 0 \\
\hline & & G2 & 10 & 0 & 0 & 0 & 3 & 7 & 0 & 0 & 0 & 130 \\
\hline & & G3 & 10 & 0 & 0 & 0 & 0 & 6 & 3 & 1 & 0 & 226.2 \\
\hline & & G4 & 10 & 0 & 0 & 0 & 2 & 3 & 5 & 0 & 0 & 197 \\
\hline \multirow{4}{*}{41} & \multirow{4}{*}{$\begin{array}{l}3^{\text {rd }} \text { week post } \\
\text { challenge }\end{array}$} & G1 & 10 & 10 & 0 & 0 & 0 & 0 & 0 & 0 & 0 & 0 \\
\hline & & $\mathrm{G} 2$ & 10 & 0 & 0 & 0 & 2 & 8 & 0 & 0 & 0 & 139.3 \\
\hline & & G3 & 10 & 0 & 0 & 0 & 0 & 6 & 2 & 2 & 0 & 242.5 \\
\hline & & G4 & 10 & 0 & 0 & 0 & 3 & 3 & 4 & 0 & 0 & 171 \\
\hline
\end{tabular}

GMT: Geometeric mean titer. G1: Blank control. G2: Infected non treated group. G3:Vaccinated infected group. G4: Probiotic treated infected group.

Table 6. ELISA mean optical densities of antibodies in sera of broiler chickens after vaccination with the locally prepared S. Enteritidis bacterin and treatment with probiotic

\begin{tabular}{|c|c|c|c|c|c|c|}
\hline Age/day & Intervals & $\begin{array}{l}\text { Blank control } \\
\text { group }\end{array}$ & $\begin{array}{l}\text { Infected, non- } \\
\text { treated group }\end{array}$ & $\begin{array}{l}\text { Vaccinated, } \\
\text { infected group }\end{array}$ & $\begin{array}{c}\text { Probiotic } \\
\text { treated, } \\
\text { infected group }\end{array}$ & LSD \\
\hline 1 & $\begin{array}{c}\text { Before } 1^{\text {st }} \text { vaccination } \\
\text { dose }\end{array}$ & $0.234 \pm 0.064^{\mathrm{Aa}}$ & $0.234 \pm 0.052^{\mathrm{Ca}}$ & $0.234 \pm 0.032^{\mathrm{Ca}}$ & $0.234 \pm 0.039^{\mathrm{Da}}$ & 0.044 \\
\hline 10 & $\begin{array}{c}\text { Before booster } \\
\text { vaccination dose }\end{array}$ & $0.212 \pm 0.031^{\mathrm{Ac}}$ & $0.212 \pm 0.027^{\mathrm{Cc}}$ & $1.614 \pm 0.249^{\mathrm{Ba}}$ & $0.561 \pm 0.034^{\mathrm{Cb}}$ & 0.115 \\
\hline 20 & Before challenge & $0.245 \pm 0.035^{\mathrm{Ac}}$ & $0.245 \pm 0024^{\mathrm{Cc}}$ & $2.543 \pm 0.427^{\mathrm{Aa}}$ & $0.953 \pm 0.078^{\mathrm{Bb}}$ & 0.198 \\
\hline 27 & $1^{\text {st }}$ week post challenge & $0.232 \pm 0.042^{\mathrm{Ac}}$ & $1.781 \pm 0.396^{\mathrm{Ab}}$ & $2.281 \pm 0.366^{\mathrm{Aa}}$ & $1.574 \pm 0.375^{\mathrm{Ab}}$ & 0.298 \\
\hline 34 & $2^{\text {nd }}$ week post challenge & $0.231 \pm 0.050^{\mathrm{Ac}}$ & $1.457 \pm 0.346^{\mathrm{Bb}}$ & $2.340 \pm 0.294^{\mathrm{Aa}}$ & $1.845 \pm 0.452^{\mathrm{Aa}}$ & 0.291 \\
\hline 41 & $3^{\text {rd }}$ week post challenge & $0.241 \pm 0.033^{\mathrm{Ad}}$ & $1.274 \pm 0.339^{\mathrm{Bc}}$ & $2.486 \pm 0.444^{\mathrm{Aa}}$ & $1.779 \pm 0.458^{\mathrm{Ab}}$ & 0.328 \\
\hline \multicolumn{2}{|r|}{ LSD } & 0.039 & 0.230 & 0.298 & 0.274 & 0.274 \\
\hline
\end{tabular}

Different small letters within the same row were significantly difference at $(P \leq 0.05)$.

Different capital letters within the same column were significantly difference at $(P \leq 0.05)$.

+ ve result $=>0.65$

-ve result $<0.65$ 